\title{
Under Which Conditions Did the Greeks "Believe" in Their Myths? The Religious Criteria of Adherence
}

\author{
VINCIANE PIRENNE-DELFORGE
}

In 1987, Fritz Graf published a book entitled Griechische Mythologie. Eine Einführung, which was soon translated into English under the same title: Greek Mythology. An Introduction". This work was immediately evaluated as "the best historical survey" on the subject and this is still the case today ${ }^{2}$. Besides this essay, a large amount of work has been published by Fritz Graf, demonstrating a wide range of interests and impressive expertise. As his main concerns have always been Greek myth and religion, I would like to connect both of these themes in this modest contribution ${ }^{3}$, in order to thank our colleague and friend for his revealing and always inspiring work.

Such an ambition may seem adventurous as neither "myth" nor "religion" has been spared by the post-modern and critical dismantling of many interpretive categories or dichotomies such as muthos vs. logos. We must underline once more that "myth" and "religion" are not concepts native to the Greek language and do not have to be used as frameworks of thought ${ }^{4}$. However, the splitting-up of these categories as "ideal types" does not lessen the need to understand the narratives that we call "myths" and the Greeks called logoi or muthoi. We must also address their connection with what we call "religion", which fits in with various Greek expressions such as tà bierá ("sacred things"), tà theîa ("that which refers to the gods"), tà nómima ("that which is prescribed and refers to tradition") ${ }^{5}$. A pragmatic definition of

1 Graf (1987) and (1993).

2 Bremmer (1994) 65 n. 4. Very recently, this was still the opinion of Calame (2007) 282.

3 This paper is the English adaptation of an analysis in French included in a book on Pausanias. See Pirenne-Delforge (2008) 64-85.

4 See, in particular, Detienne (1981), Calame (1991) and (1996) 9-55, esp. 46.

5 On the definition of "myth", see Des Bouvrie (2002) 11-69. On the different Greek words referring to "religion", see Rudhardt (21992) 11-17, and (2008). 
Greek "myth" might describe it as a narrative rooted into the knowledge shared by a society, i. e. a traditional story referring to the representation of the past shared by this specific human community and to the representation of the gods and the world framing its current life ${ }^{6}$. Such narratives are transformed during oral performance or written composition but these variations are not aleatory. They are restricted within certain limits and such a capacity for adaptability is a measure of their vitality.

What has for a long time been interpreted as a gradual transition from muthos to logos and as the Greek move towards enlightenment has been largely questioned for at least two decades 7 . In fact, the expressive power of "myth" and its capacity to illustrate the truth in one way or another survived the early Classical period, when its cultural and religious relevance began to be called into question. Furthermore, "mythical" narratives seem to have incited critical debate as early as their first appearance in our Greek literary heritage. The proem of Hesiod's Theogony is a beautiful example of such a potentiality, with a contrasted speech attributed to the Muses.

Two verses spoken by the goddesses and directed to the "shepherds that camp in the wild, disgraces, merest bellies" $"$ provide a contrast to fic-

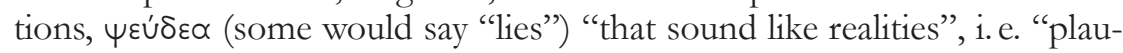
sible fictions", on the one hand, and "truths", $\alpha^{\prime} \lambda \eta \theta \dot{\varepsilon} \alpha$, on the other". Both propositions are endorsed by the Muses, who underline their own capacity to perform the first as well as the second kind of address according to their own good will ${ }^{10}$. Fictions as well as truths are connected with divine inspi-

6 Cf. Graf (1993) 1-8. Even if "myth transcends the text" (2), narratives are our best tool for grasping myths.

7 See for example the critical essays gathered in Buxton (1999), among which we find Fritz Graf's article entitled "Mythical Production: Aspects of Myth and Technology in Antiquity".

8 Hes. theog. 26, transl. West (1988) 3.

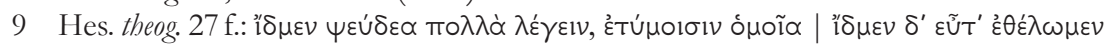

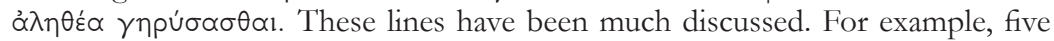
papers were presented on this issue during a conference held in Lille and entitled "Hésiode et le métier du mythe": Judet de La Combe/Blaise/Rousseau (1996). My own reflection owes much to the article published by Jean Rudhardt in this book. See also Daix (2006), Pucci (2007) 60-70, and Heiden (2007), whose work is briefly discussed in the following note.

10 The expression "lies that resemble truth" from verse 27 , is generally thought to refer to polemic against a rival poetry. Such a common opinion was recently addressed by Bruce Heiden arguing that homoios does not mean "resemblance so close as to be deceptive" but "the same with respect to a certain quality": Heiden (2007), with previous bibliography. Following a suggestion made by Marie-Christine Leclerc in 1993, the author aims at demonstrating that the Hesiodic Muses claim to tell only the truth because their lies were somehow equivalent to truth. So far so good. In this respect, however, the opposition between alethea and pseudea remains, even 
ration and refer to what we call "mythical" narratives, which are, as early as the Hesiodic poetry, themselves related to critical assessment. Different levels of "truth" are connected with the goddesses themselves. The poet's own position in these matters certainly consists of claiming a higher degree of truthfulness for the inspiration poured onto his own lips by the Muses ${ }^{11}$. "Mythical" narratives therefore constitute a group of tales in which both plausible fiction and truth may potentially be present, unless truth strays far from the standards of plausibility. I shall return to this point.

Criticism of myths must not merely be seen as a peculiar stage of the reading of traditional tales, as has been thought for a long time. This critical posture is deeply embedded in the system and is a fundamental part of it since rivalry seems to be present as early as Hesiod's poetry. Hence our difficulty in grasping this and accounting for such a rich and multiform whole. Quoting Geoffrey Lloyd, I might say that some puzzling statements "have, no doubt, to be understood, in each case, against a background of a rich and complex set of beliefs, that are gradually acquired by the members of the society concerned, a set that contains more and less central, more and less secure, items, some open to doubt, others requiring specialist or learned interpretation, and yet others passing as unquestioned or axiomatic"12. Distinguishing one context of discourse ${ }^{13}$ from another is necessary for defining to what degree statements may be left undisputed or, on the other hand, open to challenge.

In the Hesiodic account of the poet's encounter with the Muses at the foot of Mount Helicon, truths are related to emphatic and authoritative statements $(\gamma \varepsilon \rho u ́ \varepsilon \sigma \theta \propto l)$, which need not necessarily require likelihood, while fictions seem to be more closely connected with reality and are plausible. These two verses entail some notions that will become fundamental tools in the ancient and modern reflection about Greek myths: truth, fiction, likelihood. Many authors, at each stage of the long-standing Greek cultural life, might be taken into account in order to illustrate the coexistence of these notions as far as "myths" are concerned. Skipping centuries, I choose

though the philological analysis of homoios is highly convincing. Following Chan-

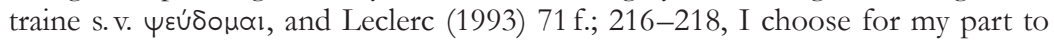
understand pseudea as "fictions". Since the word etuma points to "sensible realities" and not "truth" as alethea may do, we recapture an understandable opposition between "plausible fictions" and "truth", i. e. lifelikeness on the one hand, and truth on the other, even though such a truth - alethea - does not necessarily fit in with reality. From this perspective, the Muses do not tell deceptive lies but their inspiration points to several levels of "truth". See also Daix (2006).

11 Graf (1993) 79: "Hesiod claims to hear the truth in person."

12 Lloyd (1990) 27.

13 What Buxton (1994) calls the contexts of mythology in the subtitle of his work Imaginary Greece. 
Pausanias and his journey into the cultural landscape of Roman Greece in order to decipher some of the criteria he used to express his adherence to mythical narratives. This is not mere chance as Paul Veyne, in his short book Did the Greeks Believe in Their Myths?, quoted a range of examples from Pausanias' work ${ }^{14}$.

One of these examples comes from the beginning of the eighth book of Pausanias' Periegesis, where he displays the genealogical succession of the Arcadian kings. Pelasgus was the first king who ruled over the region and he civilized its inhabitants. Lycaon, the next king, was even wiser than his father in his actions but, in matters of religion, his choices were less judicious. He sacrificed a new-born child to the Zeus he had called Lycaeus, while his contemporary Cecrops offered cakes to Zeus Hypatos on the acropolis of Athens. After the sacrifice, Lycaon was immediately turned into a wolf (8.2.1-3). At this point, Pausanias interrupts the story in order to assess this statement (8.2.4):

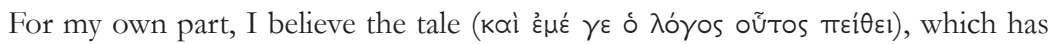

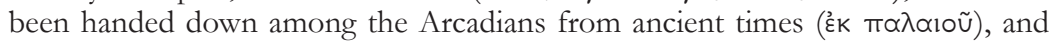
has likelihood (tò zikós) in its favour. For the men of that time, because of their

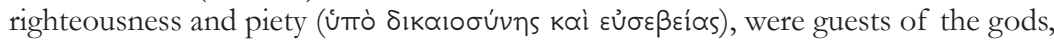
and sat with them at table. [...] Men were raised to the rank of gods in those days, and are worshipped down to the present time ${ }^{15}$.

However, times have changed. Pausanias denounces the sin of his own age, on the one hand, and the human capacity of building falsehood upon

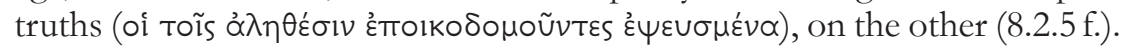

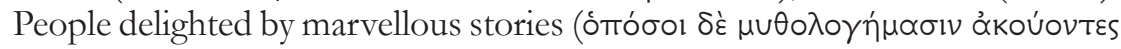

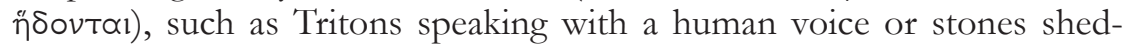
ding tears, have corrupted truthful issues by mixing them with fictions (Toĩs

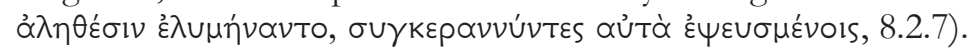

In this passage, Pausanias makes a strong distinction between a metamorphosis into a wolf supported by ancestral tradition, hence rooted in times of piety, and the same phenomenon connected with more recent times, which therefore becomes incredible fantasy ( $\left.\mu v \theta 0 \lambda \operatorname{co}_{\gamma} \eta \mu \alpha\right)$. The traditional Arcadian discourse is believable insofar as the quality of the period to which it refers may be placed high on a moral and religious level, even though metamorphosis is an issue normally open to challenge by Pausanias ${ }^{16}$. Deciphering his expressions of belief implies an understanding of the distinction he draws between different kinds of tale. On the one hand, we find muthologemata, conceived as marvellous tales involving heroic achievements

14 Veyne (1988; French original 1983). Cf. Buxton (1994) 155-158.

15 On the issue of "gods born of human beings", see Pirenne-Delforge (2009 forthcoming).

16 Paus. 1.30.3; 1.41.9; 6.8.2f. 
and fantastic bestiary. On the other, there are credible stories, which are not necessarily plausible in their materiality (metamorphosis sounds strange in this respect) but are supported by specific arguments.

Another passage further in the same book authorizes such a qualification and sheds light on its implications. Pausanias has just told the Arcadian version of the story of Cronus swallowing his own children: Zeus was supposed to have escaped from his father's voracity but so was Poseidon, since Rhea first gave her husband a horse instead of the new-born god, just as she did afterwards, substituting a stone for Zeus ${ }^{17}$. Whereas he often maintains a silence about such local stories, which he meticulously reports without a commentary ${ }^{18}$, Pausanias interrupts his discourse once more to comment on this Arcadian tale. The passage is well-known and has been much commented upon ${ }^{19}$ :

When I began to write my synthesis, I was inclined to count these Greek stories

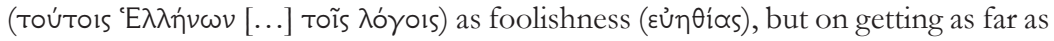
Arcadia I grew to hold a more thoughtful view of them, which is this. In the days of old, those Greeks who were considered wise spoke their sayings not straight out but in riddles ( $\delta \imath^{\prime}$ aivl$\left.\gamma \mu \alpha \dot{T} T \omega v\right)$, and so the stories about Cronus I conjectured to be one sort of Greek wisdom. In matters of divinity, therefore, I shall adopt the received

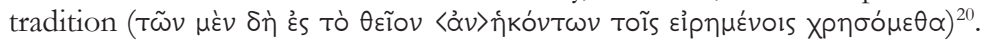

This passage is a welcome addition to Pausanias' previous statement about muthologemata, a word which does not appear here ${ }^{21}$. In fact, "these Greek logoi", thought to be foolish before travelling the roads of Arcadia, point to the well-defined category of stories referring to gods.

The swallowing of one's own children is a strange divine behaviour and this conception of the gods had already been denounced by philosophers centuries earlier ${ }^{22}$. Nevertheless, we may suspect such a behaviour to have been included among the Hesiodic alethea. In this respect, Pausanias gives evidence of two ways of addressing these stories: rejecting them as foolishnesses, on the one hand, and, on the other, respecting them as "riddles" to be carefully reported, since they were handed down by a tradition deeply rooted in a community. The register of the enigmatic, which means hidden

17 Paus. 8.8.2.

18 Pausanias echoes Herodotus' statement that he must report tales without necessarily believing them: Hdt. 7.152; cf. Paus. 6.3.8. See Pirenne-Delforge (2008) 26, 30-32.

19 Oliver (1972); Veyne (1983) 106-110; Elsner (1992) 21; Habicht (21998) 156 f.; Hartog (1996) 151-158; Jost, in Jost/Casevitz (1998) XXXIII-XXXVI; Hutton (2005) 303-311; Pirenne-Delforge (2008) 71 f., 337-341.

20 Paus. 8.8.2 f. (translation adapted from W.H.S. Jones).

21 On the rare occurrences of this semantic field in the Periegesis, see Pirenne-Delforge (2008) 82-86.

22 Graf (1993) 178-191. 
discourse about the divine, implies a suspension of judgement insofar as it is anchored in a remote past, an age of piety and respect. All the other tales are open to challenge, which implies the need to read them with a critical eye in order to identify truthful elements of the Greek past, which have been saturated by marvellous and incredible concretions. These other tales refer to human actions including the heroic sphere.

The ten books written by Pausanias are full of interesting places where he discusses stories. Sometimes foolishness is denounced. For example, how might we suppose that the inhabitants of Troy had been deceived by a wooden horse? Everyone must be aware that Epeus constructed an engine for breaking down the wall ${ }^{23}$. The reality of the Trojan War is left undisputed as such but the details must be corrected. In the same vein, at Sparta, a statue dedicated to Aphrodite by Tyndareus represented the goddess as having fetters on her feet. One of the aetiologies explained this particularity by referring to Tyndareus' will to punish Aphrodite because she was at the origin of his daughters' shame ${ }^{24}$. The historicity of this consecration is not put into doubt but the validity of the aetiology is contested. At Olympia, Pausanias describes a tablet recording the victories of the Spartan Chionis and considers as very simple those who believe that Chionis himself dedicated the tablet since one of the recorded races had not yet been introduced when Chionis was alive. Pausanias' framework for evaluation is the same whatever period he is dealing with: he wants to provide a trustworthy report but plausibility may be the only achievement of his investigations. When investigation completely fails, he places different versions one beside the other without taking on any particular position. The account of local traditions is sometimes associated with an interjection of incredulity, which

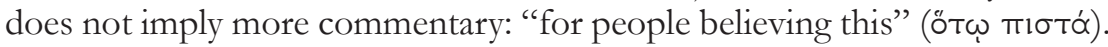
Twice, the expression refers to the underworld ${ }^{25}$ and three passages refer to the marvellous capacities of things or heroes ${ }^{26}$. At Thebes, Pausanias uses a significant expression, which might be a commentary on his own position in such matters. He is visiting the agora of the city and he says: "The Greeks who believe that the Muses sang at the wedding of Harmonia can point to the place in the market-place where they say the goddesses sang." ${ }^{27}$ Whatever its credibility, the story is closely connected with a definite place and the autopsy of such places is an essential component of Pausanias' journey.

23 Paus. 1.23.8.

24 Paus. 3.15.11.

25 Paus. 2.5.1; 2.31.2.

26 Paus. $2.31 .10 ; 4.2 .7 ; 9.10 .1$.

27 Paus. 9.12 .3 (transl. J.G. Frazer): 'E

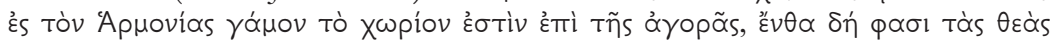
$\tilde{\alpha} \sigma \alpha l_{1}$. 
Since the visitor firstly aimed at preserving the Greek heritage in all its local and particular components, critical assessment only remained an option and was not obligatory. Such narratives left undisputed were nevertheless virtually open to challenge. This was one option among others. The very limit of Pausanias' critical approach was defined by what he called to theion in one of the passages of book eight quoted above: "In matters of divinity, I shall adopt the received tradition."

Accordingly, we may point out three possibilities in Pausanias' framework for evaluation, when he opts for discussion:

- narratives involving heroes, thought to be actors of the Greek past, are open to critical assessment, regarding genealogical and narrative cohesion;

- narratives involving heroes, who are more or less saturated with fantasy, are challenged;

- narratives involving gods are seen as "riddles" to be left unquestioned. Nevertheless, things are not that simple. There are intersections between these three kinds of tale. Narratives involving heroes may be stripped of their marvellous concretions in order to dig out a kernel of truth. Furthermore, some parts of the narratives are related to gods or traditional ritual acts and should be left undisputed for that reason. The second and third options are closer than we might suspect. This is the point I would like to address now.

My first example comes from the first book and is related to Pausanias' visit to Megara, where he mentions a temple to Apollo and his sister Artemis that is said to have been built by Alcathous, son of Pelops, after slaying the monstrous lion of Cithaeron. The beast was ravaging the land and the king Megareus had promised that whoever should slay the lion would marry his daughter. A classical heroic challenge, indeed. Megareus had already lost two sons, one killed by the lion and the other by Theseus. Alcathous succeeded, got the girl and the throne, and consecrated the temple of the twin deities as thanksgiving. So the tale goes, concludes Pausanias (1.41.3). We would have been left alone with this tale but Pausanias, as author, interferes in his text with a critical statement (1.41.4): “Though I wish to conform to the Megarian tradition, I am unable to do so on all points." He must face a chronological and genealogical problem: since Theseus is a descendant of Pelops, Theseus would not have killed the son of Alcathous who was himself a son of Pelops. The Megarians are not reliable on this point but the very conclusion of the whole argument is significant (1.41.5): "As far as Alcathous and the lion are concerned, whether it was on Cithaeron or elsewhere that the killing took place, he built a temple to Artemis Agrotera

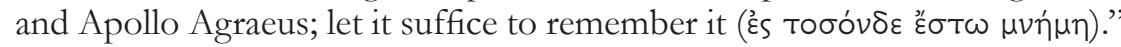
This passage is very indicative of the way in which Pausanias tackles the various elements he encounters during his journeys. Buildings are the concrete 
supports of memory ${ }^{28}$. Even though heroic and genealogical narratives may be challenged and questioned, monuments related to cults contribute to the rooting of the piety of the present in a remote past. Alcathous' pious consecration does not need to be called into question as such, only the genealogical manipulations need to be. Instead, the following example will be more expressive.

In the ninth book, which refers to Pausanias' visits to Boeotia, the sceptre of Chaeroneia is a curiosity all the more worth mentioning as this object is the most honoured of the gods by the inhabitants (9.40.11: $\theta \varepsilon \tilde{\omega} \nu \delta \dot{\varepsilon}$

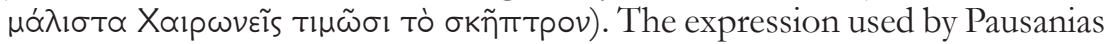
closely connects the honours paid to this object with the cult performed by other cities in honour of their poliadic deity. The divine status of the sceptre derives from its history. Homer says that Hephaestus made the sceptre for Zeus, Hermes received it from Zeus and gave it to Pelops, who left it to Atreus, Atreus to Thyestes. Agamemnon finally obtained it from Thyestes. The sceptre probably arrived in Phocis with Electra as intermediate, and was finally obtained by the inhabitants of Chaeroneia, who called it Spear. It has no public temple, but is kept by its priest in a private house. Every day, all sorts of offerings are displayed on the table by its side. The sceptre is worshipped as a god would be. Furthermore, Pausanias states that "there

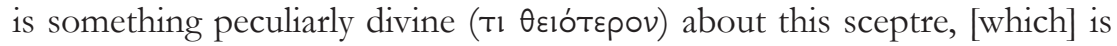
most clearly shown by the fame it brings to its owner" (9.40.11), but he does not specify the nature of such a fame. The visitor is faced with common cultic features, known elsewhere as traperomata ${ }^{29}$, related to something completely uncommon but tremendously ancient, full of divine brightness and deeply rooted in a long-standing ritual performance. The peculiar status of the sceptre was closely connected with its divine origin, as Hephaestus was said to be its craftsman. Pausanias might have left this point unchallenged, since a divine power is said to be at work behind the main cult of a local community. Instead, he argues extensively for the genuineness of the sceptre, which is said to be the only piece of art really worked by Hephaestus. Three other pieces of work attributed to the divine craftsman are discussed and their authenticity denied. The argument deserves close attention.

The first object is a bronze bowl kept in the temple of Apollo at Patara in Lycia. Telephus was said to have dedicated this work of Hephaestus. Pausanias dismisses the claim, as the Lycians apparently ignore the fact that the first to melt bronze were two Samians who were living some generations after Telephus. The second item is the chest brought by Eurypylus from Troy, which is assumed to be kept by the Patreans. However, this piece is not exhibited for inspection at Patras. The third and last object is the famous

28 On this point, see Hutton (2005) 127-174; Pirenne-Delforge (2008) 32-40.

29 Gill (1974). 
necklace given to Harmonia as a wedding present. It was identified with a jewel conserved in the sanctuary of Adonis and Aphrodite at Amathus on Cyprus. The necklace is made of green stones fastened together with gold, while the Odyssey describes the necklace finally given to Eriphyle as being made of gold, although Homer was not ignorant of jewels composed of different materials (9.41.1-5). Accordingly, as Pausanias concludes, likelihood (Tò cikós) implies that the sceptre is the only work of Hephaestus.

Firstly, Pausanias' argument refers to two sources of information: poetic songs and human opinion transmitted from one generation to another (9.41.1: $ं \Phi \eta \mu \eta)$. The poetic songs are a good starting point, and they are all the more reliable as the poet is Homer himself. The opinions passed down are a weak source and are open to deformation. Therefore, each claim has to be assessed according to various criteria. The claim of the Lycians regarding the bronze bowl is unwarranted because of the relative chronology of metallurgy, a surprising argument as far as a divine work is concerned ${ }^{30}$. The chest of Eurypylus cannot be dated with precision, as the Patreans do not have it on display. Pausanias' scepticism is certainly based on his own visit to the city, where he extensively refers to the origin of the chest and to its role in the history and the rituals of the place. Due to the fact that the chest was carried outside Dionysus' sanctuary on one night during the festival of the god, it was difficult for the visitor to be present at this moment ${ }^{31}$. The necklace kept in Amathus cannot be Harmonia's famous jewel because of a contradiction between its materiality and the Homeric description. Finally, Pausanias did not prove the authenticity of the sceptre. He only denied the same quality to the other pieces of work assumed to be the results of Hephaestus' skill. The "likelihood", the eikos, related to the genuineness of the sceptre in his conclusion is not the logical consequence of the argument. In fact, its support lies at another level of Pausanias' discourse, i.e. inside the daily honours paid to an object not only depending on the divine sphere but really taking on a divine status. The weight of a long-standing ritual is a powerful criterion in favour of the work's authenticity. Likelihood does not result from an argument built on a strong historical assessment but from a qualitative evaluation deeply anchored in ritual performance.

Accordingly, the antiquity of a discourse is not necessarily an unequivocal criterion. Let us take the example of the marvellous tale narrated by the inhabitants of Tanagra in Boeotia about a Triton. In the sanctuary of Dionysus, Pausanias saw such a fantastic beast and he took the opportunity to describe this kind of animal, which he had also seen in Rome, along

30 The same argument is provided for refuting the attribution of a dedication to Ulysses (Paus. 8.14.7f.). This is less intriguing in this case, as the episode is only related to the human world.

31 Paus. 7.19.6; 7.20.1. 
with many other beasts he had never seen before. Two tales are narrated to explain why a Triton has been conserved in this sanctuary. The most vener-

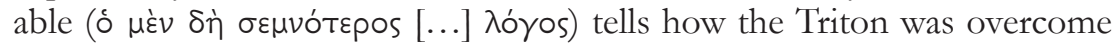
by the god prayed to by his female worshippers who were present on the sea-shore to be purified before performing his orgia. The other story is not

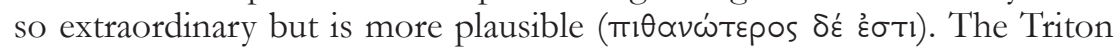
used to devastate the territory and carry off all the cattle till the inhabitants set out a bowl of wine for drinking. They finally caught the beast in this manner. They said that Dionysus had killed the Triton because he had been drunk (9.30.4f.). Here we face the human ability to elaborate marvellous stories. On the other hand, as far as the sceptre is concerned, a venerable story is closely related to ritual. This is a strong distinction. In stories related to divine agency, the religious criterion of adherence is all the more efficient as the story is rooted into a ritual performance or a cult-place.

Narcissus' story will be our last example, among many others that might have been chosen. Narcissus' spring located in the district of Thespiae is related to the death of the young man, supposed to have fallen in love with his own reflection. Pausanias does not subscribe to the story and provides another explanation. Narcissus had a twin sister, with whom he was in love. When the girl died, he found some comfort in looking at his own image reflected in the waters of the spring, imagining he was seeing his sister. But Narcissus is also the name of a flower and Pausanias goes forward with this detail. He is persuaded that the flower grew many years before Narcissus the Thespian and was therefore independent of him. The proof is found in a poem of Pamphus telling the tale of Kore, the daughter of Demeter, who was carried off by Hades when she was gathering a marvellous narcissus growing miraculously in order to deceive her. Since Pamphus is an old poet, born many years before Narcissus, this means that Narcissus did not give his name to the flower (9.31.7-9). There are three levels to the argument: firstly, the criterion of likelihood is applied to the story of Narcissus' death, as a man of good sense would not fall in love with himself; secondly, a chronological measure separates Narcissus the man from the flower of the same name; thirdly, the tale of Kore raped by Hades receives no comment, as it belongs to those traditions about the divine that are left unquestioned and unchallenged.

Did Pausanias believe in myths? In fact, such a question misses the point because it takes as a whole several types of narrative that need to be distinguished: the mass of heroic stories alleged to encompass the remote past of the communities, on the one hand, the tales related to deities, on the other, those which are partially seen as ancestral wisdom. Human imagination and 
the taste for marvellous tales have built upon both of these sets of stories - this is the poetic fantasy - or have adapted some of them to search of identity and legitimization - this is the misappropriated use of genealogy.

Between Hesiod and Pausanias, centuries passed and the relevance of such tales has been more and more called into question: leaving the world of poetic inspiration, narratives about the past have been submitted to different questions and new analytical frameworks, by those who wanted to search for things of the past. Hecataeus' laughter when faced with the silly stories of the Greeks was a first step and the most radical option was taken by Thucydides deciding to put aside all of what he called muthodes, "mythic stuff", in his own work ${ }^{32}$. Without addressing all these well-known developments, let us point out the fact that Pausanias is not as far away from the double statement of the Hesiodic Muses as the chronological gap might lead us to suppose. What remains strongly is the religious dimension of the aletheia as a true but enigmatic discourse about the divine world. On the other hand, one part of the semantic field of aletheia seems to be alien to the inspired perspective of Hesiod and is more closely connected with the critical assessments of Hecataeus: the credible story is what is left when fantasy and embellishments have been cut out.

Pausanias' work attests to complementary attitudes as far as truth is concerned. A first level points out the hidden truth of the cosmogonic and theogonic tales, for which the main reference is Hesiod and his authoritative statements. A second level concerns the narratives improved by a critical work that makes them credible, just as Hecataeus seemed to practise in the poorly preserved fragments of his work. But the multiplicity of local traditions often hinders such an improvement. Therefore, this third level points out Herodotus' way of addressing such traditions: he aims at setting down what is told, without necessarily believing $\mathrm{it}^{33}$, a statement that is quoted almost exactly by Pausanias in the sixth book of his work ${ }^{34}$.

Critical assessments are halted by the necessity of setting down traditions as far as divine agency is concerned, on the one hand, and by the weight of long-standing ritual performance at a local level, on the other. If such a reserve is not a literary and intellectual posture inspired by the spirit of the time, we must change the wording of the question about Pausanias' belief. We should not wonder whether Pausanias believed in myths but why he gave credence to some myths and not to others.

The answer lies in the background of the narratives and is closely related to the authority with which Pausanias credits them. Adhering to such a statement as "Cronus swallowed his own children" is not the fearsome

32 Thuc. 1.21.1. See Graf (1993) 122-124.

33 Hdt. 7.152.

34 Paus. 6.3.8. 
consequence of a deficient rationality but the expression of the trust placed in the traditional background to which such a proposition belongs. Furthermore, both poetry and prophecy are closely connected with the register of ainigmata from the earliest days, when gods were still inspiring elected human beings ${ }^{35}$. The literal significance of a statement may be puzzling, but the source of the knowledge that informs it is indisputable and adherence results from this confidence.

Cognitive anthropology has shown that we can roughly divide the domain of beliefs into two parts: intuitive beliefs on the one hand, which are connected with our approach to the natural world and therefore shared by various cultures, reflexive beliefs, on the other, which depart more or less seriously from our commonsense ideas. In this context of "counterintuitive" beliefs, the source of authority is an essential component ${ }^{36}$. The adherence to a statement as difficult to understand as "Cronus swallowed his own children" is possible in a group if the authority that conveys it is strong enough. Such information belongs to the knowledge shared by the group and forms the culturally determined beliefs. If authority fails to maintain its force, adhesion will become weaker or disappear, but transmission will nevertheless go on through the centuries ${ }^{37}$.

Returning to Pausanias, we may build on this theoretical approach. Collecting Greek traditions is the main purpose of his work. The knowledge shared by a Greek community, even on a local level, belongs to what he calls panta ta Hellenike ${ }^{38}$. However, inside this huge heritage, not all the narratives imply the same level of adherence. This adherence is all the stronger as the tale is rooted in ancient poetic statements related to the representation of the divine. It is effective too if a ritual performance attests at the present time a long-standing veneration. In the 2 nd century $\mathrm{AD}$, poetic performance no longer provides authoritative statements, as the rhapsodes and choruses of earlier times might have done. Hence authoritative validation has to come from elsewhere, in particular from ritual performance, related to monuments of the past. An example taken from Plato's Phaedrus should make this point clear, by placing such a process as early as the Classical period. Socrates and Phaedrus are walking along the Ilissus River and discussing the tradition of Oreithyia's rape by Boreas. Socrates points out that the alleged location of this event is some furlongs farther down, where there is an altar to Boreas. Then, Phaedrus asks him if he believes the tale (muthologema) is true.

35 On this point, see a revealing statement by Pausanias: 10.12.11. On ainigmata, see Struck (2005).

36 See Boyer (1994); Sperber (1996) 97-102.

37 Sperber (1996) 133.

38 Paus. 1.26.4. See Elsner (1992) 14; Hutton (2005) 55-58; Pirenne-Delforge (2008) 27-29. 
Socrates' reply is in fact a charge against any rational interpretation of such stories. He criticizes the "rustic sort of wisdom" that tries to explain each tale in accordance with probability and concludes on the statement that he

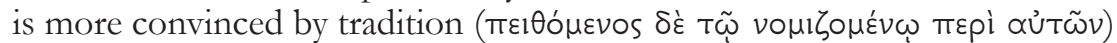
on these matters than by these pseudo-explanations without end ${ }^{39}$. In this case, tradition is surely connected with the altar erected to Boreas in this place and with the honours paid to this god at the local level. This passage might be an echo of what we find in the eighth book of Pausanias centuries later, when he forcefully states that, in matters of divinity, he will adopt the received tradition.

In 1972, James Oliver noted that there was nothing different in the Arcadian tales to account for what he called Pausanias" "conversion", since Athenian logoi, for instance, were equally ancient and hence authoritative ${ }^{40}$. He tried to demonstrate that the Panathenaic discourse of Aelius Aristides could have influenced Pausanias when he was writing his Arcadian book, therefore producing a new awareness of the value of old stories. By contrast, Paul Veyne suggested that the experiencing of Arcadia itself, with its remote traditions, engendered the visitor's new respect for these $\log _{0} i^{41}$. Others related this experience to some philosophical interest in Stoic allegorical interpretation ${ }^{42}$. Veyne is surely correct in his statement that Arcadia itself was a turning-point, even though we must be conscious that Pausanias' self-presentation does not exactly reflect some genuine experience, one that is rarely accessible, if ever. Old Arcadian stories might have had an impact, but rituals must also be taken into account. Only twice within his ten books does Pausanias state that he personally performed a sacrifice. The first occurred on the island of Aegina, in the sanctuary of Damia and Auxesia where he states that "[he] saw the images and sacrificed to them according to the ritual observed in sacrificing at Eleusis" 43 . The second sacrifice was performed in the Arcadian town of Phigalia, where the Black Demeter received bloodless offerings, also consecrated by the visitor ${ }^{44}$.

Still on a ritual level, many mystery cults related to Demeter and her daughter were attested in Arcadia, among which the cult of Despoina at Lycosoura was the most important for all the inhabitants of the region ${ }^{45}$. As far as the content of the mysteries is concerned, we are left in the dark by

39 Plat. Phaedr. 229-230c.

40 Oliver (1972) 319.

41 Veyne (1983) $109 \mathrm{f}$. Cf. Hutton (2005) $306 \mathrm{f}$.

42 E.g. Habicht (21998) 156-159, esp. 159; Rutherford in: Alcock/Cherry/Elsner (2001) 47.

43 Paus. 2.30 .4 (transl. J. G. Frazer).

44 Paus. 8.42.14.

45 Paus. 8.37.9. See Jost (2003). 
Pausanias, who adopts the silent posture of an initiate ${ }^{46}$. Nevertheless, the mythical background of the cult encompasses some important motives such as the story of Poseidon turning into a male horse in order to mate with Demeter who tried to escape him disguised as a mare ${ }^{47}$. The goddess was honoured as Erinys and Lousa in Telphousa, in memory of this event, but the fact that Despoina was born from this union implies that this tale was also part of the cult of Lycosoura. Despoina's father was called Hippios, an epiclesis much attested in Arcadia for Poseidon. His sanctuary at Mantineia had been reconstructed by the emperor Hadrian, who had prevented some workmen from looking into the ruins enclosed inside the new building. The entrance of the old temple built by Trophonius and Agamedes was forbidden and merely protected by a woollen thread, which was respected by pious people except for one, who died after having cut it ${ }^{48}$. This Poseidon is closely related to horses, but zoomorphic motives also characterize Demeter herself, as well as the punishment Zeus inflicted on Lycaon, turning him into a wolf. Furthermore, excavations held on the site of the sanctuary at Lycosoura have brought to light standing terracotta figurines with animal heads, and the sculpted veil of Despoina was decorated with characters disguised as animals ${ }^{49}$. These elements make it possible to suggest that animal motives were all the more important during the performance of the mysteries as many local myths were also imbued with such references.

Piety, close proximity between deities and men, between deities and animals, primordial sacrifices to the Black Demeter, strange rituals in the cult of Zeus Lycaeus, and finally Lycosoura, assumed to be the oldest city in the world, form a range of elements to take into account in the assessment of the impact of the local mysteries on the way Pausanias changed his mind. The authority of the Arcadian traditions in matters of "religious anthropology" and their anchorage in the primeval ages of the world is so powerful that even implausible stories with regard to good sense and natural laws have to be respected. In this local context, such tales, rooted in performance, reclaim a relevance that would be disputed in others.

Pausanias' text is important for the study of Greek "myth" and "religion". On the one hand, this work offers rich evidence that would have disappeared if its author had not dealt with so many local monuments, peculiarities or obscure traditions. On the other, the visitor provides evidence of two positions

46 Paus. 8.25.7; 8.37.9.

47 Paus. 8.25.4-7.

48 Paus. 8.10.2-4.

49 Jost (2003) 157-163. 
regarding this material: he is at the same time an insider who participates in the system he describes and an observer who tries to interpret the evidence from the outside. The distinction between these positions is often difficult for us to draw but the Arcadian "conversion" attests that it can shift insofar as the field of experience is still open and alive in the 2nd century AD.

Pausanias was the privileged witness to the present investigation precisely because of his ambition to describe "all that was Greece". Other contemporary writers would have been read in this perspective. For instance, Arrian offers an interesting remark at the beginning of the fifth book of his Anabasis of Alexander, where he refers to the city of Nysa. The city is said to be a foundation of Dionysus after he had submitted the Indians. But who was this Dionysus? When did he live and where did he come from? Arrian refuses to address these questions, stating that "this is not necessary to provide a close examination of the myths from the remote past regarding the divine: what seems to be incredible as far as plausibility is concerned does not seem unbelievable at all if one adduces the divine to the tale" ${ }^{50}$. Arrian infers that tales related to divine agency cannot be investigated with the same methods as the evidence connected with human agency and implies therefore a suspension of judgement. The respective aims of Pausanias and Arrian are not exactly the same, but as far as stories related to deities are concerned, standards of plausibility may be undermined without necessarily undermining credibility. Adopting a received tradition in its own context is one of the best ways of addressing these narratives. Plutarch's treaties and biographies would also provide a large range of statements showing the necessity, for an insider observer, of assessing religious feelings and adherence to traditional tales according to the context of the discourse that encapsulates them ${ }^{51}$.

Already in Hesiod's Theogony, plausible fiction and truth may potentially be present in the discourse of the Muses and truth itself far away from standards of plausibility. The metaphoric power of tales related to divine agency therefore does not imply their rejection as foolishness without taking into account the context of their enunciation, i. e. the particular authority of the voice that supports them. For Pausanias, this fact became obvious in Arcadia.

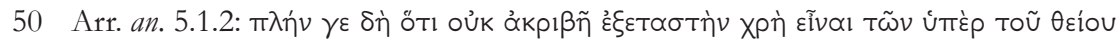

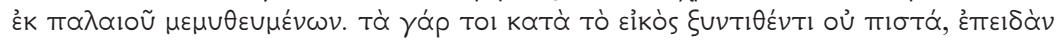

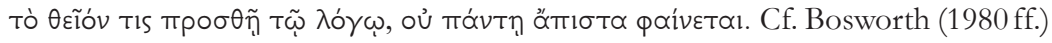
vol. 2, 202.

51 Plut. Cam. 6.5 f. See Veyne (2005). 


\section{Bibliography}

Alcock/Cherry/Elsner (2001). - Susan Alcock/John Cherry/Jaś Elsner (eds.), Pausanias. Travel and Memory (Cambridge 2001).

Bosworth (1980 ff.). - Albert Brian Bosworth, A Historical Commentary on Arrian's "History of Alexander", vol. $1 \mathrm{ff}$. (Oxford $1980 \mathrm{ff}$.).

Boyer (1994). - Pascal Boyer, The Naturalness of Religious Ideas (Harvard 1994).

Bremmer (1994). - Jan Bremmer, Greek Religion, Greece \& Rome. New Surveys in the Classics 24 (Oxford 1994).

Buxton (1994). - Richard Buxton, Imaginary Greece. The Contexts of Mythology (Cambridge 1994).

Buxton (1999). - Richard Buxton (ed.), From Myth to Reason? Studies in the Development of Greek Thought (Oxford 1999).

Calame (1991). - Claude Calame, "'Mythe' et 'rite', des categories indigenes?”, Kernos 4 (1991) 179-204 (= id., Sentiers transversaux. Entre poétiques grecques et politiques contemporaines, ed. by David Bouvier, Martin Steinrück, and Pierre Voelke, Grenoble 2008, 43-62).

Calame (2007). - Claude Calame, "Greek Myth and Greek Religion", in: Roger D. Woodard (ed.), The Cambridge Companion to Greek Mythology (Cambridge 2007) $259-285$.

Daix (2006). - David-Arthur Daix, "Réalités et vérités dans la Théogonie et Les Travaux et les Jours d'Hésiode", Mètis n.s. 4 (2006) 139-164.

Des Bouvrie (2002). - Synnøve Des Bouvrie, "Introduction", in: ead., Myth and Symbol, vol. I: Symbolic Phenomena in Ancient Greek. Culture. Papers from the First International Symposium on Symbolism at the University of Tromso, June 4-7, 1998 (Bergen 2002) 11-69.

Detienne (1981). - Marcel Detienne, L'invention de la mythologie (Paris 1981).

Elsner (1992). - Jaś Elsner, "Pausanias: A Greek Pilgrim in the Roman World", Past \& Present 135 (1992) 3-29 (reprinted in: Robin Osborne [ed.], Studies in Ancient Greek and Roman Society, Cambridge 2004, 260-285, with a postscript 2003).

Gill (1974). - David Gill, "Trapezomata. A Neglected Aspect of Greek Sacrifice”, Harvard Theological Review 67 (1974) 117-137.

Graf (1987). - Fritz Graf, Griechische Mythologie. Eine Einführung (München/Leipzig 1987). Graf (1993). - Fritz Graf, Greek Mythology. An Introduction (Baltimore 1993).

Habicht (21998). - Christian Habicht, Pausanias' Guide to Ancient Greece (Berkeley ${ }^{2} 1998$ [1985]).

Hartog (1996). - François Hartog, Mémoire d’Ulysse. Récits sur la frontière en Grèce ancienne (Paris 1996).

Heiden (2007). - Bruce Heiden, “The Muses’ Uncanny Lies: Hesiod, Theogony 27 and Its Translators", American Journal of Philology 128 (2007) 153-175.

Jost (2003). - Madeleine Jost, "Mystery Cults in Arcadia", in: Michael B. Cosmopoulos (ed.), Greek Mysteries: The Archaeology and Ritual of Ancient Greek Secret Cults (London 2003) 143-168.

Jost/Casevitz (1998). - Madeleine Jost/Michel Casevitz, Pausanias. Description de la Grèce, vol. 8: Livre 8: L'Arcadie (Paris 1998).

Judet de La Combe/Blaise/Rousseau (1996). - Pierre Judet de La Combe/Fabienne Blaise/Philippe Rousseau (eds.), Le métier du mythe. Lectures d'Hésiode, Cahiers de Philologie publiés par le Centre de Recherche philologique de l'Université Charles de Gaule-Lille, 16. Série Apparat critique (Lille 1996).

Leclerc (1993). - Marie-Christine Leclerc, La Parole chez Hésiode (Paris 1993). 
Lloyd (1990). - Geoffrey E. R. Lloyd, Demystifying Mentalities (Cambridge 1990).

Oliver (1972). - James H. Oliver, "The Conversion of the Periegetes Pausanias", in: Homenaje a Antonio Tovar (Madrid 1972) 319-321.

Pirenne-Delforge (2008). - Vinciane Pirenne-Delforge, Retour à la source. Pausanias et la religion grecque, Kernos Suppl. 20 (Liège 2008).

Pirenne-Delforge (forthcoming). - Vinciane Pirenne-Delforge, "Reading Pausanias: Cults of the Gods and Representation of the Divine", in: Jan Bremmer/Andrew Erskine (eds.), The Gods of Ancient Greece: Identities and Transformations (Edinburgh 2009).

Pucci (2007). - Pietro Pucci, Inno alle Muse (Esiodo, Teogonia, 1-115). Testo, introduzione, traduzione e commento, Filologia e Critica 96 (Pisa 2007).

Rudhardt (21992). - Jean Rudhardt, Notions fondamentales de la pensée religieuse et actes constitutifs du culte en Grèce ancienne (Paris ${ }^{21992, ~ G e n e ̀ v e ~ 1958) . ~}$

Rudhardt (2008). - Jean Rudhardt, "Essai sur la religion grecque", in: id. Opera inedita, Kernos Suppl. 19, ed. by Philippe Borgeaud and Vinciane Pirenne-Delforge (Liège 2008) 33-56.

Sperber (1996). - Dan Sperber, La contagion des idées. Théorie naturaliste de la culture (Paris 1996).

Struck (2005). - Peter T. Struck, "Divination and Literary Criticism?", in: Sarah Iles Johnston/Peter T. Struck (eds.), Mantikê. Studies in Ancient Divination (Leiden 2005) 147-165.

Veyne (1988). - Paul Veyne, Did the Greeks Believe in Their Myths? (Chicago 1988, French original: Les Grecs ont-ils cru à leurs mythes? [Paris 1983]).

Veyne (2005). - Paul Veyne, "Les problèmes religieux d'un païen intelligent, Plutarque", in: id., L'Empire gréco-romain (Paris 2005) 633-681.

West (1988). - Martin West (trans.), Hesiod: Theogony and Works and Days (Oxford 1988). 